\title{
DEVELOPMENT OF APPROACHES TO ENSURE RELIABLE EMERGENCY COMMUNICATIONS IN EMERGENCIES
}

\author{
Mohammed Omar Ahmed Abdulvasea, \\ Taiz University, Taiz, Yemen, \\ omaralmu20I2@mail.ru
}

\begin{abstract}
Keywords: Emergency, Call center, Throughput, Unmanned aerial vehicles, Profes-sional radiotelephone communication, Multiservice traffic.
\end{abstract}

Saving the lives of people suffering from emergencies is the most important task facing any state. The speed of response of rescue systems depends on their ability to interact and ensure reliable communication between the population and the organizations that are responsible for rescue services. The article is devoted to the search for solutions to ensure sustainable communication in emergencies. The article offers options for solving two different problems that arise during the development of emergencies. One of the consequences of the emergency is a sharp increase in the number of calls by the population to rescue services, the pos-sible partial destruction of rescue systems, as well as a breakdown in communica-tion between the population and response points. The first task is to increase the capacity of call centers to detect emergencies, monitor the situation, inform the public and reduce panic. The second task - is providing emergency communication between rescue services. To solve this problem, use TETRA professional radiotelephone equipment as an alternative to mobile communication systems that can be disabled or disabled.

Information about author:

Mohammed Omar Ahmed Abdulvasea, Graduate student of the Department of Communication Networks and Switching Systems MTUCl, Moscow, Russia;

Taiz University, Taiz, Yemen

Для цитирования:

Мохаммед О.А.А. Разработка подходов к обеспечению надежной экстренной связи в условиях чрезвычайных ситуаций // Т-Сотт: Телекоммуникации и транспорт. 2020. Том I4. №I. С. 42-48.

For citation:

Mohammed O.A.A. (2020) Development of approaches to ensure reliable emergency communications in emergencies. T-Comm, vol. I4, no. I, pp. 42-48. (in Russian) 
The level of development of states can be assessed by the level of introduction of telecommunication technologies to ensure convenience for residents, as well as to as sist them in emergencies. The transition from autonomous call centers of emergency services (CC ES) to their integration into the system helps to attract additional resources for service calls in emergencies. The need for combining and operational processing of emergencies traffic in a single duty dispatch services (SDDS) has led to the introduction of Systems112, with the help of which access to several operational services is carried out by one number 112 .

The development of emergencies leads to a rapidly increase in traffic directed to call centers ES. Consequently, the call centers ES cannot support the established indicators of quality of service (QoS).

As shown in Figure 1, during emergencies, real-time communication traffic (telephone communication) is especially rapidly growing. A quick response is important to rescue the victims $[1,2]$.

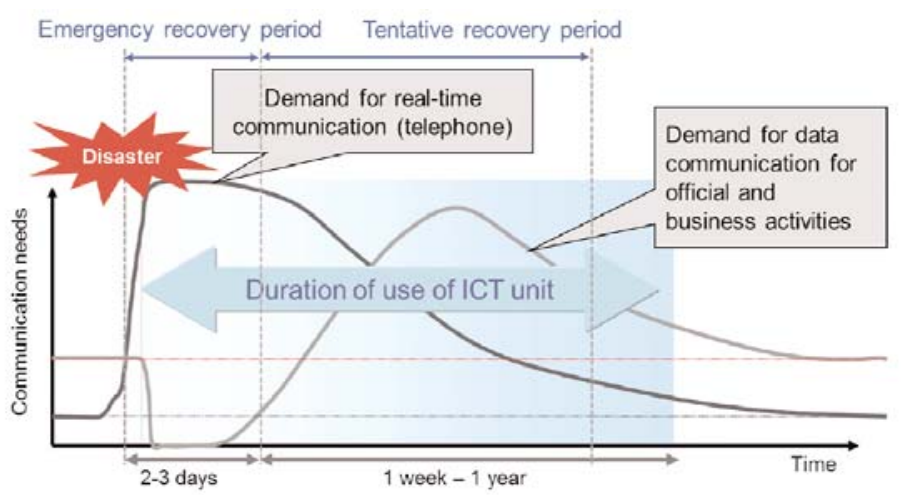

Figure1. Traffic increase during Emergency

Call centers of the "System 112" should fix the emergence of emergencies and, as a result, transfer the response systems in emergency mode.

In some situations, it is difficult to predict occurrence of emergencies based on data from traditional warning systems. We can offer such a sequence to switch to emergency mode.

1. We fix a certain number of calls, numerically equal to the number of operators in the call service center; we denote it by the value $(C)$.

2. Set this value as a threshold value.

3. A certain time interval $t$ is fixed for observing the process of incoming calls (it can be assumed that $t$ is equal to the time of one session, that is, the time during which one call is served).

4. In each time interval, the number of incoming calls is recorded IC $(\mathrm{t})$.

5. Comparison performed of the number of incoming calls in the time interval $t$ that was denoted as with a threshold value.

6. If the number of incoming calls in the time interval $t$ is greater than the threshold value, then the occurrence of an emergency announced, and the emergency mode is switched on

$$
X(t)= \begin{cases}\text { if } C<I C(t) \text { to } & N O \text { Emergency } \\ \text { if } C \geq I C(t) \text { to } & Y E S \text { Emergency }\end{cases}
$$

Function $x(t)$ - the appearance of emergency during the time $t$.

After switching on the emergency mode, the task is to increase Throughput of call centers of emergency services (CC ES)

We list the list of factors of multidirectional influence on the throughput of "System 112":

- $\quad$ Structure choice - distributed, centralized, mixed;

- Allocation of a special center for operational reserve;

- Combining in emergency mode the resources of several call service centers;

- Selection of traffic distribution method in emergency mode.

Under normal conditions, the throughput is high enough and the "System 112" ensures reliable communication. In emergency mode, everything changes and the quality of service decreases. To increase the throughput in call centers, a special method must be developed. The first two factors are difficult to change (it means the choice of structure and allocation of resources). The third and fourth factors can be used to provide high throughput. Based on them, can be chosen a method for combining call centers of emergency services (CC ES), and develop a method for distributing excess traffic.

One of the manifestations of an emergency can be the blocking of various elements of the emergency call center. Proposed solutions should consider this possibility. A high availability ratio is required to ensure due to the provision of a sufficient reserve.

This article proposes a solution for the task by combining the resources of several call centers of emergency services (CC ES), to increase the throughput of the SDDS system as a whole.

From the point of view of queuing theory, it is possible to consider emergency call service centers as a multichannel system $[1,3,4]$. If the emergency mode is fixed in one area, the thread of emergency calls to one specific emergency call service center is increasing. It is necessary to increase the number of operators in the CC ES taking into account the expected emergency traffic. Part of the operator's workplaces was not be used, because emergencies are quite rare. To reduce costs when deploying new operator jobs, significant redundancy is laid down for devices and line-cable structures. By providing a connection between call centers in different regions using fiber-optic rings, we get the fundamental possibility of serving a large part of the excess traffic with the resources of those CCES that are not affected by the emergency.

Figure two shows a variant of the organization of interaction between different CC ES on fiber-optic communication lines. In this case, a special center for operational response has been set up (CC ES OR), resources which are available to several CC ES. That is, for each of the CC ESs, it provides for the possibility of reroute excess traffic to the call center CC ES OR. The mathematical model and calculation results of this option published in article [3].

The positive aspects of using the rapid response center are:

- Efficient service of excess traffic from several call centers of ES in the service areas of which emergencies occurred at the same time;

- The possibility to take into account the geographical factor, including call centers of regions and settlements distant from each other in the $\mathrm{CC}$ of the $\mathrm{OR}$, which reduces the risk of critical congestion when several emergencies occur simultaneously. 
- $\quad$ The possibility to provide operational mutual assistance to several call centers at the same time;

This option has a significant drawback, consisting in the irrationality of the use of the operational response center, the equipment that used only in emergencies.

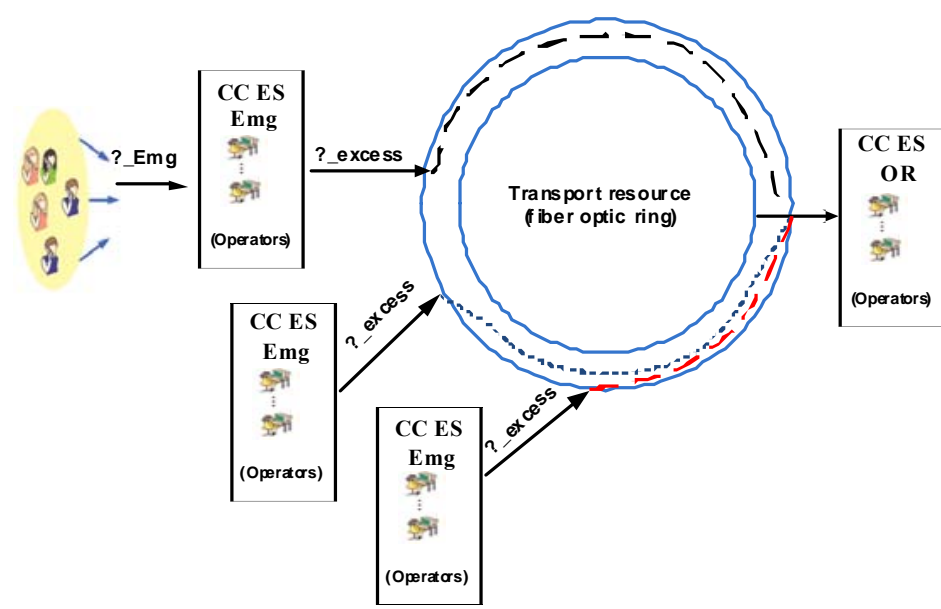

Figure 2. The use of fiber optic rings for interconnecting an EC call center

In Figure 3 another variant of the organization of mutual assistance between CC ESs is presented. This takes into account the need to maintain a sufficiently high level of emergency call service in areas where there is no emergency, but the resources that are used to service excess traffic.

The functional diagram of this option presented in Figure 3. The operational management methods ORR (Overflow Reroute) and COR (Cancel Reroute Overflow) are used. Consider applying the Overflow Reroute method. The principle of its operation is that when any CC ES goes into lock mode (all operators are busy), the ORR method activated in this call center. Unserved calls to this call center are redirected to other CCES.

When a redirected call incomes at the CC ES, which is unavailable due to the busyness of all operators or due to the management functions involved by the network, the call goes in a circular pattern to the next call center (CC ES). If not all CC ESs are available for a redirected call, the call receives information from the IVR interactive voice menu system. Part of the load is serviced in the CC ES - Emg (emergency call service center, in the service area of which the emergency is recorded).

Excess traffic from it is sent through a distributor to call centers of the mutual assistance system, the volume of such traffic is set in proportion to the real capacity of these CC ES. Figure 3 shows a simplified sample. The number of centers to be combined can be established taking into account real conditions. Between the CC ES, it may be possible to transfer excess traffic along the mutual assistance chain.

It is possible to use the interactive voice menu IVR in each call center or only the last one in the chain of call center ES. A load that does not receive service in the system is routed to this IVR.

We describe emergency call service in two stages based on the theory of teletraffic. The first stage involves the calculation of excess traffic using the first Erlang formula. Excess traffic expression

$$
\lambda_{\text {Excess }}=\mathrm{p}_{\mathrm{B}} * \mathrm{~A}_{-} E \mathrm{mg} \text {, }
$$

Where $\lambda_{\text {Excess }}$ is the intensity of the arriving load in call center in the emergency zone; $p_{\text {Call }}$ - expression for assessing the probability of call loss, characterizing the state "all operators are busy"

$$
\mathrm{p}_{\text {Call }}=\mathrm{E}_{V_{-} E \mathrm{mg}}\left(\mathrm{A}_{E \mathrm{mg}}\right)=\frac{\mathrm{A}_{\mathrm{чc}} V_{-} E \mathrm{mg}}{\sum_{i=0}^{V_{-} E \mathrm{mg}} \mathrm{A}_{E \mathrm{mg}}{ }^{i} / \mathrm{i} !} .
$$

An important is the recurrence relation, which allows making calculations according to the first Erlang formula using a computer

$$
\mathrm{E}_{V_{-}}\left(\mathrm{A}_{E \mathrm{mg}}\right)=\mathrm{A}_{E \mathrm{mg}} * \mathrm{E}_{V_{E \mathrm{mg}}-1}\left(\mathrm{~A}_{E \mathrm{mg}}\right) /\left(V_{E \mathrm{mg}}+\mathrm{A}_{E \mathrm{mg}} * \mathrm{E}_{V_{E \mathrm{mg}}-1}\left(\mathrm{~A}_{E \mathrm{mg}}\right)\right)^{\cdot(3)}
$$

In the event of an emergency in the service area of several call centers, excess traffic is determined based on the RDA method ( $\mathrm{R}$ is the average value of the excess load; $\mathrm{D}$ is its dispersion; $\mathrm{A}$ is the load intensity). The expression for calculating excess traffic from several call centers is defined as the sum of the flows of excess traffic

$$
\lambda_{\text {Excess_sum }}=\sum_{J=1}^{\mathrm{M}} \lambda_{\operatorname{Excess}(\mathrm{M})}
$$

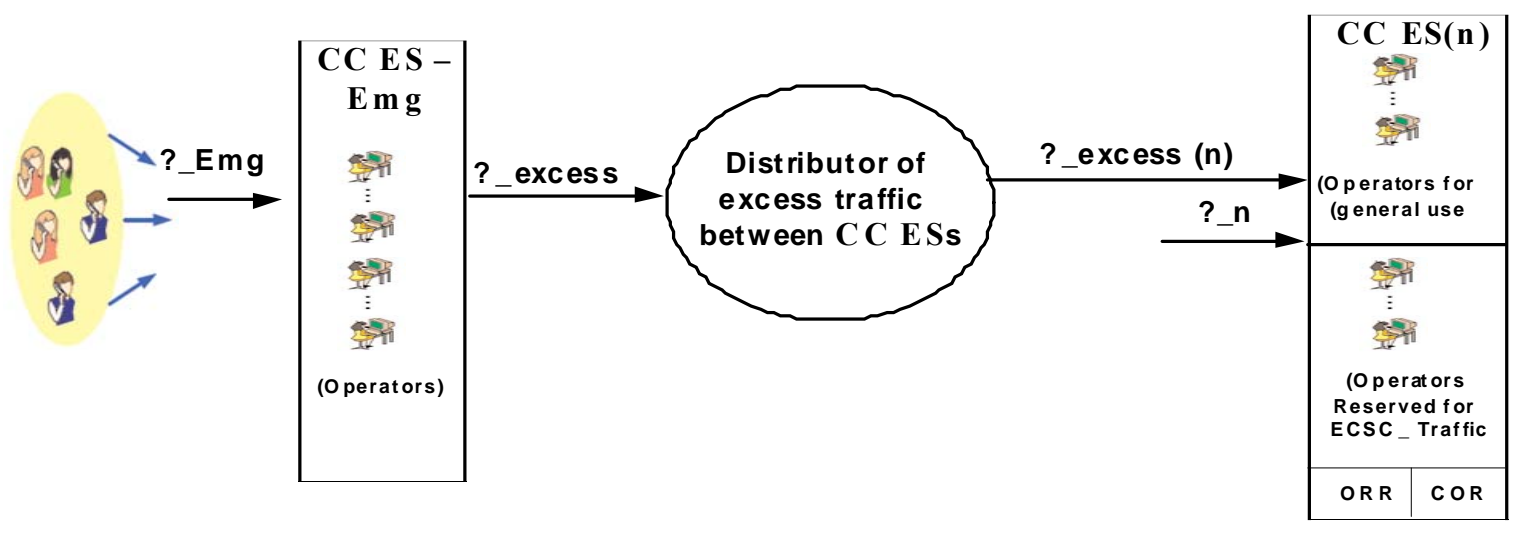

Figure 3. Variant of organization of a distributed system of mutual assistance 
The second stage as sumes a mathematical description of the operation in the call center. Suppose there are V operators. Two Poisson streams arrive (see Fig. 3). The time between calls and the duration of their service are distributed exponentially with the parameters, accordingly, $\lambda$ and $\mu-$ for the stream coming from the call center CC ES-ES (it can be called an excess stream) and the second stream with parameter $\lambda \nu$ and parameter $\mu$. We denote by the $\varphi$ number of operator jobs reserved for servicing calls coming from the call center (n). Using the indicator function, the system of equations of probabilistic characteristics can be written in the form of a single relation.

$$
\begin{aligned}
& P(i)=\frac{\mathrm{P}(\mathrm{i}+1)(\mathrm{i}+1) \mu \mathrm{I}(0 \leq \mathrm{i} \leq \mathrm{V}-1))}{\left(\lambda \mathrm{n}+\lambda_{\text {excess }(\mathrm{n})} \mathrm{I}(0 \leq \mathrm{i} \leq \varphi)+\lambda_{\text {excess }(\mathrm{n})} \mathrm{I}(\varphi<i \leq V-1)\right.} \\
& \mathrm{v}=0,1 \ldots \mathrm{v}-1, \\
& \mathrm{P}(\mathrm{v}) \mathrm{v}=\mathrm{P}(\mathrm{v}-1) \lambda_{\text {excess (n) }} .
\end{aligned}
$$

System of equations (5) has a unique solution that can be obtained using linear algebra methods. We use the iteration method for solving $[3,4]$. We present the calculation results for a specific example. In the conditions of standardization of SDDS for large cities, it is important to use call center (CC ES) with the same capacity. According to statistics, during emergencies a fivefold increase in traffic in the emergency response center (CC ES-Emg) was recorded.

The number of centers combined in a single system was calculated. Suppose the average value of the intensity of the load in each of the central heating facilities is $10 \mathrm{Erl}$. When emergencies emerge, $A_{E m g}$ rises to 50 Erl. To cope with overloads, it is necessary to calculate the necessary number of operators in each of the call center of the system $(\mathrm{Vj})$ and necessary number of centers, to which excess traffic is directed (W), as well as the number of reserved operators in the centers (Vrez). As the calculation showed, with $\mathrm{Vj}=30$, it is necessary to combine four emergency call service centers $(\mathrm{W}=3)$. That is, the capacity of call center is 30 operators, of which three operators in each of the centers are included in the operational reserve and serve traffic only in their area of responsibility. The total number of call centers integrated into a mutual assistance system is four, since $\mathrm{W}$ is three. Under these conditions, the system will withstand five-fold overload. Figure 4 shows the dependence of the potential stability coefficient of the emergency call center to overloads on the number of channels of the operational reserve Vjrez at $\mathrm{Vj}=30, \mathrm{~W}=3$, $\mathrm{Aj}=10 \mathrm{Erl}$. The coefficient of potential resistance of the emergency call center to overloads is defined as $h=A c h s / A j$.

Another factor that affects throughput is the method of managing excess traffic. Various control methods may be used. Traffic management is understood as the establishment of control under the quality of real-time information servicing for delivery to the end user, and ensuring the efficient use of network resources. On communication networks, regardless of the switching technologies used, and the network structure.

We list four principles of controlling the intensity of teletraffic: support for calls that with high probability can end conversation, in order to reduce the impact of inefficient traffic on work the network; connection; providing priority to the direct path of establishing a

- use of available free network resources;

- $\quad$ prevention of overload of switching systems.

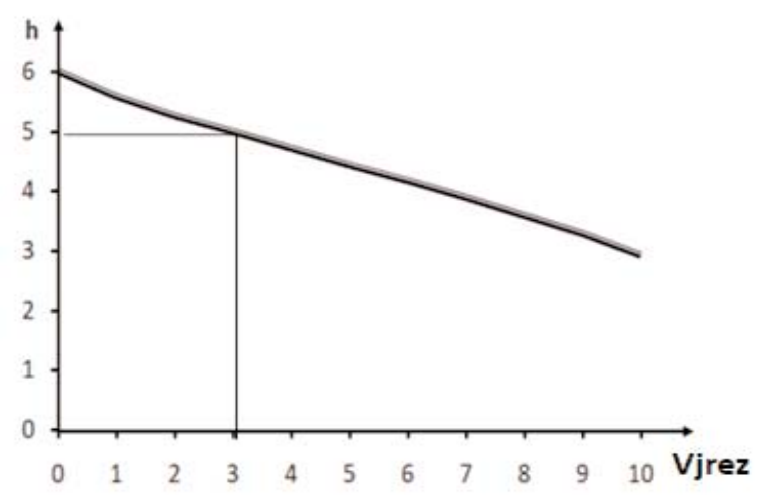

Fig. 4. The dependence of the coefficient of potential stability of the call center on overload $h$ to the number of channels of the operational reserve Vjrez

One of the important factors of communication management in emergencies is to ensure the continued functioning of communications, to achieve which they use a number of technical approaches and systems for backup and recovery. The availability of communication systems and the duration of their functioning can be affected by both physical damage caused to the network because of an emergency and its overload immediately after a disaster. Figure 5 shows statistics on the use of communications facilities after the earthquake in Japan in March 2011. As the graph shows, there was a sharp increase in the number of attempts to use the mobile network, but such attempts were not successful, due to network congestion and the small number of available base stations [2].

To reduce overload in conventional communication paths, it is possible to recommend the use of various portable communication systems (Portable Emergency Communications System) as an alternative in emergencies.

In emergencies, as an alternative means of communication when overloading mobile networks, it is promising to use the TETRA open standard digital trunked radio communications [5]. The prospects of the digital standard TETRA (TErrestrial Trunked RAdio) for creating professional trunked communication networks in the Russian Federation are recognized. Comparison of professional radio communication standards $[6,7]$ according to the main characteristics (technical, functional capabilities, provided communication services) showed that, The TETRA standard is the most technologically advanced professional radiotelephone standard with the largest installed base in the world. The TETRA digital radio communication system has the ability to operate in three communication modes - halfduplex, duplex, and multimedia traffic transmission.

GSM and LTE technologies using unmanned aerial vehicles (UAVs) can be used for the rescue system (see ITU recommendations) [2]. There is a high probability that such technologies will not be available for use (threat of terrorist acts). Can be adapted the TETRA standard to serve role of GSM and LTE. In practice, we are talking about the possibility of using the TETRA standard in duplex mode and multimedia mode. When using the capabilities of TETRA standard equipment, it can be considered from the point of view of teletraffic theory as a queuing system (QS) with group arrive of customers (customers from the source in half-duplex mode, customers from the source in duplex mode, and, at the end, customers from the source in multimedia mode). 


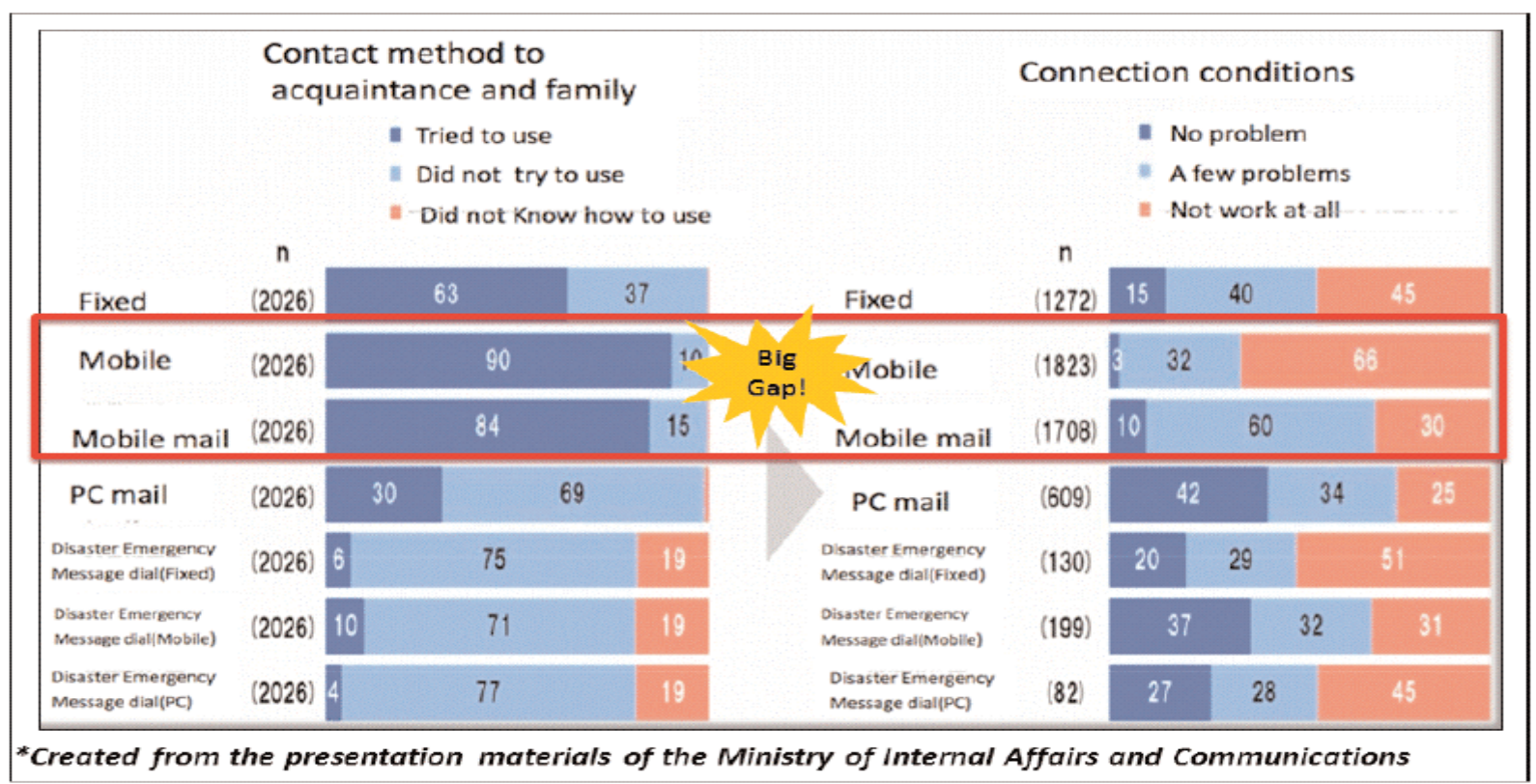

Fig. 5. Statistics on the use of communications facilities after the earthquake in Japan in March 2011

To describe this system, methods of the teletraffic theory are used. The relationship between the size and nature of the information load, the number of channels and quality of service is established. The general statement of the problem is as follows.

Let $\mathrm{V}$ be information channels in the TETRA standard. Service discipline with failures. The Poisson stream of group customer of random composition arrives to the system. This means that at time $\mathrm{t}$ with only a certain probability $\mathrm{F} 1$ there can be only one cus tomer, and with probability F2, two customers. In our case, there are three communication modes. The half-duplex mode corresponds to F1 - the probability that a customer arrives from the source in half-duplex mode and one radio channel is required for its maintenance. Duplex mode corresponds to F2 the probability that the customer arrives from the source in duplex mode and two radio channels are required for its maintenance.

The communication mode taking into account multimedia corresponds to $\mathrm{F} 8$ - the probability that a customer arrives from a source in multimedia mode and requires several radio channels to service it (suppose in this case that you need 8 radio channels).

We present a system of equations for the mathematical description of the functional model

$$
\begin{gathered}
\mathrm{p}_{1}=\frac{\lambda}{\mu} * \mathrm{p}_{0} ; \\
\mathrm{p}_{\mathrm{i}+1}=\frac{\lambda+\mathrm{i} \mu}{(\mathrm{i}+1) \mu} * \mathrm{p}_{\mathrm{i}}-\frac{\lambda}{(\mathrm{i}+1) \mu} \sum_{s=1}^{\mathrm{i}} \mathrm{F}_{\mathrm{s}} * \mathrm{P}_{\mathrm{i}-\mathrm{s}} \quad \mathrm{i}<\mathrm{V} \\
\ldots \ldots \ldots \ldots \ldots \ldots \ldots \ldots \ldots \ldots \ldots \ldots \ldots \ldots \ldots \ldots \ldots \ldots \ldots \ldots \ldots \ldots \ldots \ldots \ldots \ldots \ldots \ldots \ldots \\
\mathrm{p}_{\mathrm{v}}=\frac{\lambda}{v \mu} \sum_{\mathrm{k}=1}^{\mathrm{v}} \mathrm{P}_{\mathrm{v}-\mathrm{k}} \sum_{s=\mathrm{k}}^{\mathrm{i}} \mathrm{F}_{\mathrm{s}},
\end{gathered}
$$

$\lambda$ - the stream density of groups of customers; $\mu$ - service parameter; $\mathrm{V}$ - number of radio channels in the TETRA system.
Blocking probability in half-duplex mode:

$\mathrm{p}_{\text {ot } k_{\text {Half-dublex }}}=\mathrm{p}_{v}$.

Blocking probability in duplex mode:

$\mathrm{p}_{\text {ot } \kappa_{\text {Duplex }}}=\mathrm{p}_{v}+p_{v-1}$.

Blocking probability in multimedia mode:

$\mathrm{p}_{\text {ot } \mathrm{K}_{\text {Multe }}}=\sum_{i=0}^{m} p_{v-i}($ In our example $\mathrm{m}=8)$.

The purpose of the research was to determine the possibility of using TETRA when working in these three modes. As the results of the research showed, professional radiotelephone communication systems are very sensitive to multimedia traffic. Its presence is permissible only in large systems with the number of radio channels of more than 24 radio channels (with V ? 96 information channels). We take into account the four-fold temporary compression of the radio channel. As shown by the dependence Potk on the intensity of the load in the radio interface of the $\alpha$ groups in Fig. 6 , at $V=64$, the appearance of multimedia traffic causes significant failures in the system.

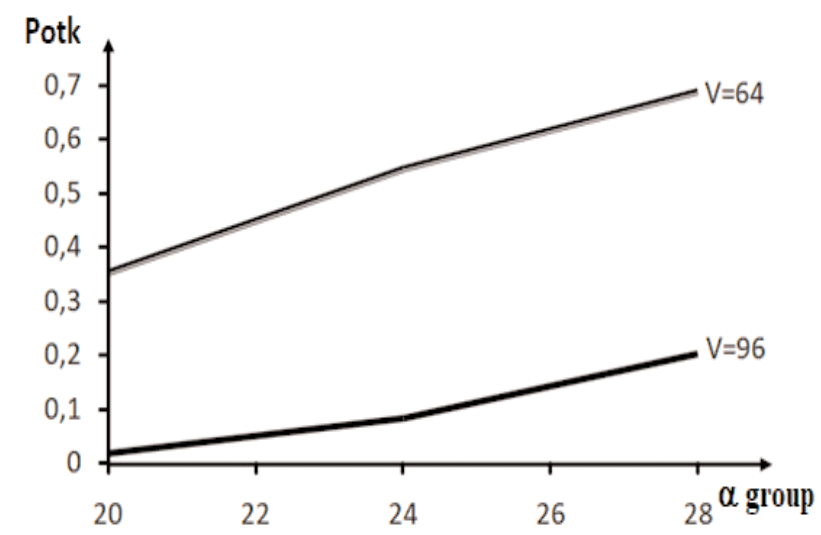

Fig. 6. The dependence of the probability of multimedia blocking (lost) Potk on the intensity of the load at F1 $=0.2 ; \mathrm{F} 2=0.6 ; \mathrm{F} 8=0.2$ 
If the TETRA system allows operation on 24 radio channels $(\mathrm{V}=96)$, then no more than five radio channels can be used for multimedia transmission. Table 1 presents the results of an analytical solution of the equation system for the TETRA standard at a different number of information channels in the radio interface, at different load intensities of the stream of customer groups for the radio interface of $\alpha$ groups.

Table 1

The results of solving the system of equations for the base station of the TETRA standard with a capacity of $V=64$ and $V=96$ information channels in the radio interface

\begin{tabular}{|c|c|c|c|}
\hline \multicolumn{4}{|c|}{$\alpha$ group $=16 \mathrm{Erl}, \mathrm{V}=64$} \\
\hline $\mathrm{F} 2$ & $\mathrm{~F} 8$ & Ротк2 & Ротк8 \\
\hline 0,91 & 0,09 & 0,006907 & 0,048485 \\
\hline \multicolumn{4}{|c|}{$\alpha$ group $=20 \mathrm{Erl}, \mathrm{V}=64$} \\
\hline 0,98 & 0,02 & 0,005887 & 0,048339 \\
\hline \multicolumn{4}{|c|}{$\alpha$ group $=24 \mathrm{Erl}, \mathrm{V}=64$} \\
\hline 0,99 & 0,01 & 0,026420 & 0,166814 \\
\hline 0,65 & 0,35 & 0,008396 & 0,046285 \\
\hline 0,95 & 0,05 & 0,000000 & 0,000001 \\
\hline \multicolumn{4}{|c|}{$\alpha$ group $=20 \mathrm{Erl}, \mathrm{V}=96$} \\
\hline 0,78 & 0,22 & 0,007913 & 0,045037 \\
\hline \multicolumn{4}{|c|}{$\alpha$ group $=24 \mathrm{Erl}, \mathrm{V}=96$} \\
\hline 0,86 & 0,14 & 0,008491 & 0,049401 \\
\hline \multicolumn{4}{|c|}{$\alpha$ group $=28 \mathrm{Erl}, \mathrm{V}=96$} \\
\hline 0,92 & 0,08 & 0,008332 & 0,050381 \\
\hline \multicolumn{4}{|c|}{$\alpha$ group $=32 \mathrm{Erl}, \mathrm{V}=96$} \\
\hline 0,97 & 0,03 & 0,006239 & 0,041978 \\
\hline
\end{tabular}

The transition to the TETRA standard during emergencies causes an increase in traffic in the TETRA network. There are two options for increasing the bandwidth of the standard TETRA network.

The first option involves the use of unmanned aerial vehicles (UAVs) as a means of reducing overload in emergency mode. The UAVs may be used as an additional resource to support communication and improve network reliability. In works $[5,6]$, the results of a research of the use of UAVs as a radio signal repeater with the aim of expanding the capabilities of groundbased radio communication systems and traffic control when network congestion occurs, and as a way to increase reliability in case of failure of a part of the network, are presented.

The UAV can be used as a search and rescue system. In this case, it can work as a repeater and a standalone element for aerial photography. The work of the search and rescue service is based on the use of equipment in the UAV that supports duplex and multimedia modes. In the ITU Recommendations, it is proposed to use UAVs in which GSM and LTE technologies are used as a search and rescue system [2]. TETRA equipment also has the same functionalities. Due to the ability to switch from one mode to another or the ability to work together in two communication modes depending on the need or situation, the TETRA standard has an advantage over other radio standards.

\section{Conclusions}

1. Combining the resources of several emergency call centers is an effective option to reduce congestion in emergency mode and provide the population with reliable information to reduce panic.

2. The performed analytical calculations made it possible to clarify the dependence of the coefficient of potential stability call center-emergency to congestion $\mathrm{h}$ on various factors, among which are the number of emergency call centers included in the mutual assistance system, as well as the amount of allocated operational reserve.

3. When address the consequences of emergencies, it is actual to use the resources of the TETRA standard in half-duplex, duplex, and multimedia modes.

4. 4. The use of UAVs with TETRA standard equipment provides an alternative to GSM and LTE standards systems, which may not be available or may be overloaded during an emergency

5. The actual use of UAVs to organize rescue of people or an alternative means of communication.

\section{References}

1. Stepanova I.V., Mohammed O.A. (2019). The method of increasing the throughput capacity of System 112 by combining the resources of a single duty dispatch services. Methodological issues of teaching infocommunications in higher education. No. 3, pp. 39 -43.

2. ITU-D 2-я study Group 2, Final Report (Question 5/2: Utilization of telecommunications/ICTs for disaster preparedness, mitigation and response6th Study Period 2014-2017.

3. Stepanov S.N. (2015). Theory of teletraffic: concepts, models, applications. Moscow: Hot line - Telecom. 868 p. (Series "Theory and Practice of Info-Communications").

4. Pshenichnikov A.P. (2017). Theory of Teletraffic. Textbook for high schools. Moscow: Hot line - Telecom. 212 p.

5. Stepanova I.V. (2017).Designing systems radio Communication TETRA standard. T-Comm. No.11, pp. 10-16.

6. Mohammed O.A.A. (2019). The results of calculating the resource of UAV channels when used in professional radiotelephone communication systems. Moscow: Abstracts at IFI-2019, pp. 82-83.

7. Website http://ess.ru Comparative analysis of digital trunking communication standards. 


\section{COMMUNICATIONS}

\section{РАЗРАБОТКА ПОДХОДОВ К ОБЕСПЕЧЕНИЮ НАДЕЖНОЙ ЭКСТРЕННОЙ СВЯЗИ В УСЛОВИЯХ ЧРЕЗВЫЧАЙНЫХ СИТУАЦИЙ}

Мохаммед Омар Ахмед Абдулвасеа, Университет Таиз, г. Таиз, Республика Йемен, отаralmu20I2@mail.ru

\section{Аннотация}

Спасение жизни людей, страдающих при чрезвычайных ситуациях, является важнейшей задачей, стоящей перед любом государством. Быстрота реагирования систем спасения зависит от их способности к взаимодействию и обеспечению надежной связи между населением и организациями, которые отвечают за службы спасения. Статья посвящена поиску решений для обеспечения устойчивой связи в условиях чрезвычайной ситуации (ЧС). Предлагаются варианты решения двух разных задач, возникающих при развитии ЧС. Одним из последствий чрезвычайной ситуации является резкий рост числа обращений населения к службам спасения, возможное частичное разрушение систем спасения, а также нарушение связи между населением и пунктами реагирования. Первая задача - увеличение пропускной способности центров обслуживания вызовов для выявления ЧС, мониторинга ситуации, информирования населения и снижения уровня паники. Вторая решаемая задача - обеспечение связи в режиме ЧС между службами спасения. Предлагается использовать оборудование профессиональной радиотелефонной связи стандарта TETRA в качестве альтернативы системам мобильной связи, которые могут быть выведены из строя или отключены.

Ключевые слова: чрезвычайная ситуация, центр обслуживания вызовов, пропускная способность, беспилотные летающие аппараты, профессиональная радиотелефонная связь, мультисервисный трафик.

\section{Литература}

І. Степанова И.В., Мохаммед Омар А.А. Метод повышения пропускной способности Системы II 2 за счет объединения ресурсов единых дежурнодиспетчерских служб // Методические вопросы преподавания инфокоммуникаций в высшей школе. 2019. №3. С. 39-43.

2. МСЭ-D 2-я Исследовательская комиссия, Заключительный отчет - (Вопрос 5/2: Использование электросвязи / ИКТ для обеспечения готовности к бедствиям, смягчения последствий бедствий и реагирования на них), 6 й Исследовательский период 2014-2017 гг.

3. Степанов С.Н. Теория телетрафика: концепции, модели, приложения. М.: горячая линия - Телеком, 2015. 868 с. (Серия "Теория и практика инфокоммуникаций").

4. Пшеничников А.П. Теория Телетрафика. Учебник для вузов. М.: Горячая линия - Телеком, 2017. 212 с.

5. Степанова И.В. Проектирование систем радиотелефонной связи стандарта TETRA // T- Соmm: телекоммуникации и транспорт. 20I7. Том II. №․ C. 10-16.

6. Мохаммед О.А.А. Результаты расчета ресурса каналов БПЛА при использовании в системах профессиональной радиотелефонной связи. М.: Тезисы доклада на МФИ-2019. С. 82-83.

7. Сайт http://ess.ru Сравнительный анализ стандартов цифровой транкинговой связи.

Информация об авторе:

Мохаммед Омар Ахмед Абдулвасеа, университет Таиз, г. Таиз, Республика Йемен; аспирант МТУСИ, Москва, Россия

\section{ГЛАВНОЕ}

\section{СОБЫТИЕ ОТРАСЛИ ИНФОРМАЦИОННОЙ БЕЗОПАСНОСТИ}
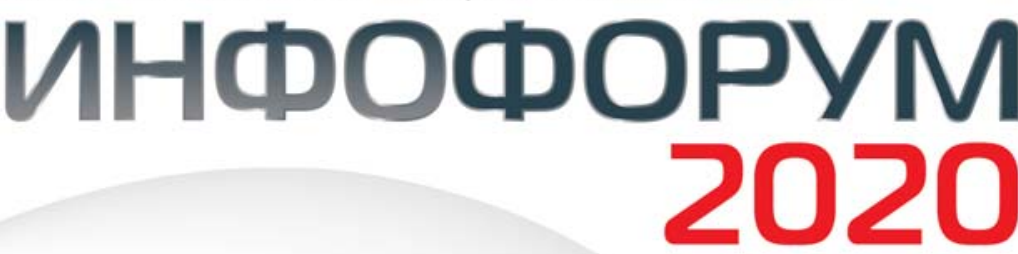

• РОССИЯ В ЦИФРОВУЮ ЭПОХУ: ПРЕОДОЛЕНИЕ РИСКОВ ИНФОРМАЦИОННОЙ БЕЗОПАСНОСТИ $22^{\text {й }}$

$$
\text { НАЦИОНАЛЬНЫЙ }
$$

ФОРУМ

ИНФОРМАЦИОННОЙ

БЕЗОПАСНОСТИ

\section{0-31 января}

здание

Правительства

Москвы

ул. Новый Арбат, 36
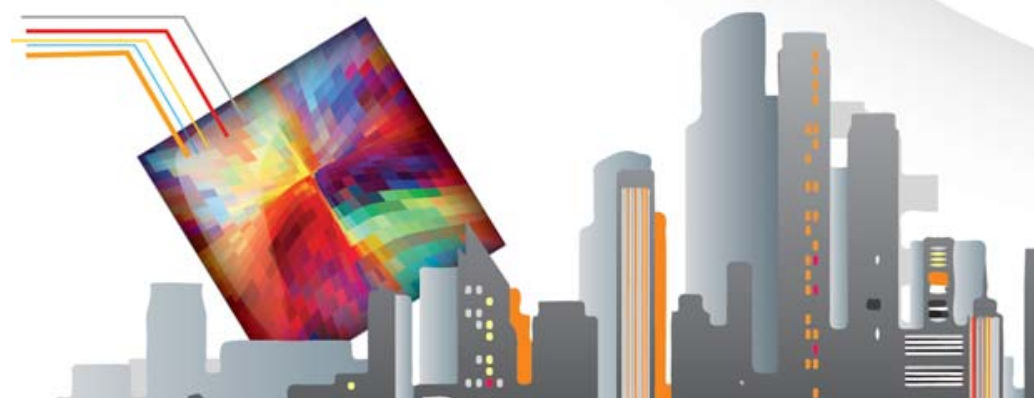

\section{infoforum.ru}

